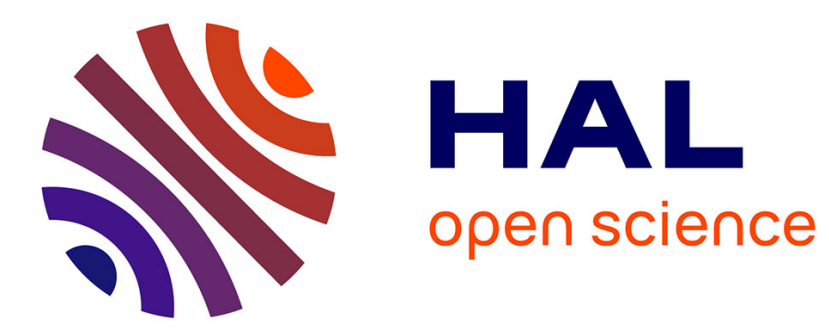

\title{
Zinc partitioning in Mediterranean rainwater
}

\author{
Rémi Losno, Gilles Bergametti, Patrick Buat-Ménard
}

\section{To cite this version:}

Rémi Losno, Gilles Bergametti, Patrick Buat-Ménard. Zinc partitioning in Mediterranean rainwater. Geophysical Research Letters, 1988, 15 (12), pp.1389-1392. 10.1029/GL015i012p01389 . hal03551134

\section{HAL Id: hal-03551134 \\ https://hal.science/hal-03551134}

Submitted on 1 Feb 2022

HAL is a multi-disciplinary open access archive for the deposit and dissemination of scientific research documents, whether they are published or not. The documents may come from teaching and research institutions in France or abroad, or from public or private research centers.
L'archive ouverte pluridisciplinaire HAL, est destinée au dépôt et à la diffusion de documents scientifiques de niveau recherche, publiés ou non, émanant des établissements d'enseignement et de recherche français ou étrangers, des laboratoires publics ou privés. 


\section{ZINC PARTITIONING IN MEDITERRANEAN RAINWATER}

Rémi Losno and Gilles Bergametti

Laboratoire de Physico-Chimfe de l'Atmosphère, URA CNRS 676, Université Paris VII

Patrick Buat-Ménard

Centre des Faibles Radioactivités, Laboratoire mixte CNRS-CEA, Gif/Yvette

Abstract. Eleven rainwater samples were collected in the Western Mediterranean region in clean conditions in order to study the partitioning of zinc between soluble and insoluble forms. The $\mathrm{pH}$ of the rainwater sampled ranges between 4 and 7 ; the high values of $\mathrm{pH}$ resulting from the neutralization of acidic species by the calcium carbonate present in desertic dusts. The soluble zinc ranged between 15 and $99 \%$ of the total zinc; the higher percentage are observed for the lower $\mathrm{pH}$, and the lower percentage for the higher $\mathrm{pH}$. This variable solubility can be explained by an adsorption-desorption equilibrium which is highly sensitive to the value of $\mathrm{pH}$ in rainwater.

\section{Introduction}

It is now clear that atmospheric inputs of trace metals to terrestrial and marine environments are dominated by wet-deposition processes, particularly in the mid-latitudes regions [Galloway et al., 1982]. Because the availability of trace metals to the marine and terrestrial ecosystems varies highly with their physico-chemical form [Moore et al., 1984; Maring and Duce, 1987; Hardy and Crecel1us, 1981], it is important to identify the parameters which control the phasechanges in rainwaters. One of the most significant interactions is the partitioning between dissolved and particulate phases. Only few data exists on trace elements partitioning in rainwater, though many studies have discussed the processes controlling the partitioning of trace elements in aquatic environments [Stumm W. and Morgan J.J., 1981; Eisenreich S.J., 1981]. From these studies, it is likely that heavy metals may be present in dissolved, colloidal or particulate fractions, may be included in minerals, may form labile or non labile complexes [Benjamin and Leckie, 1981]). The transfer of trace metal spectes from the solid to the liquid phase can result from various physico-chemical ways. First, when the trace metal is included in a mineral lattice, the exchange of cations can occur between the lattices and some other cations existing in solution. Obviously, this process will be strongly dependent on the physico-chemical properties of the particles (type of mineral lattice, particle size...). This type of solubilization will be mainly controlled by the kinetic of extraction. Second, if the trace metal is

Copyright 1988 by the American Geophysical Union.

Paper number 88GL03872.

0094-8276/88/88GL-03872\$03.00 present as salt, its solubilization will be highly controlled by $\mathrm{pH}$ and common ion effects. Finally, trace metal species can also be adsorbed on particulate or colloidal matter. There is a rapid exchange of cations (usually $\mathrm{H}^{+}$) or a desorption by complexation. In the latter case, an equilibrium between soluble and insoluble phases is attained, with the activity of the insoluble phase dependent on both the amount of insoluble metal and the number of avallable sites for adsorption. The lonic strength and espectally pH will control these adsorption-desorption processes.

To our knowledge, this paper presents the first data on the partitionfing of zinc in carefully collected individual rainwater samples characterized by a wide range of $\mathrm{pH}$. The partitioning of $\mathrm{Zn}$ in rainwater is discussed, attention being focused on the variability of soluble/insoluble ratio in relation with changes in $\mathrm{pH}$.

\section{Sampling and analytical procedures}

The samples were taken from our sampling station at Capo Cavallo $\left(42^{\circ} 31 \mathrm{~N}, 8^{\circ} 40 \mathrm{E}\right)$ on the Northwestern coast of Corsica Island. This site 1s located $300 \mathrm{~m}$ above sea-level and about $700 \mathrm{~m}$ distant from the shore line. It is exposed $80 \%$ of the time to marine air-masses from Southwest to Northeast. Moreover, the closest pollution sources originating from the city of Calvi are distant from $20 \mathrm{~km}$. Rainwater samples were collected by using ultra-clean procedures during two field experiments in March-Apr 111986 and October-November 1987 (table 1). Each rain event was collected separately by using a single-use polyethylene collector of $452 \mathrm{~cm}^{2}$ aperture. Immediately after the end of the rain, the insoluble matter was separated from the liquid phase by filtration on Nuclepore $0.4 \mu \mathrm{m}$ filter. This operation was made in a filtering hood. The liquid phase was weighted and separated into three aliquots: $10 \mathrm{ml}$ were used for immediate determinations of $\mathrm{pH}$ and conductivity; about $50 \mathrm{ml}$ were acidified with $\mathrm{HNO}_{3}$ Prolabo Normatom and stored in a teflon flask for trace metals analyses; the last aliquot was used for determination of major lons. These analyses were performed by lonic chromatography, colorimetric methods, and flame atomic absorption spectrometry. $\mathrm{HCO}_{3}^{-}$was determined by using slightly modified Gran's titration. These analyses allowed us to establish the ionic balance; the mean ratio between catlons and antons for these eleven rains was $0.94 \pm 0.07$. The trace elements analyses were performed by $X-$ Ray Fluorescence Spectrometry for the insoluble fraction [Losno et a1., 1987] and by flameless 
TABLE 1. Conditions for the rain collection and associated pH. a) Total of major insoluble elements in oxide form.

\begin{tabular}{lcrccc}
\hline Sample & Date & Time & $\begin{array}{c}\text { Volume } \\
(1)\end{array}$ & $\mathrm{pH}$ & $\begin{array}{c}\text { Total mineral a) } \\
\text { charge of insoluble } \\
\text { material (mg.1-1) }\end{array}$ \\
& & & & & \\
\hline & & & & \\
P1 & $03 / 22 / 86$ & 10 A.M. & 0.033 & 4.03 & 1.3 \\
P2 & $04 / 07 / 86$ & 10 A.M. & 0.395 & 6.88 & 17 \\
P3 & $04 / 08 / 86$ & 3 P.M. & 0.493 & 6.55 & 9 \\
P4 & $04 / 08 / 86$ & 5 P.M. & 0.214 & 5.76 & 3 \\
P5 & $04 / 08 / 86$ & 10 A.M. & 0.382 & 4.61 & 0.3 \\
P6 & $04 / 09 / 86$ & 12 P.M. & 0.218 & 4.39 & 0.5 \\
P7 & $10 / 22 / 87$ & 10 A.M. & 0.107 & 6.30 & 12 \\
P8 & $10 / 22 / 87$ & 10 A.M. & 0.030 & 6.08 & 24 \\
P9 & $10 / 29 / 87$ & 11 A.M. & 0.116 & 5.84 & 6 \\
P10 & $10 / 29 / 87$ & 2 P.M. & 0.286 & 4.94 & 2.5 \\
P11 & $10 / 29 / 87$ & 4 P.M. & 0.187 & 4.63 & 1 \\
\hline
\end{tabular}

atomic absorption spectrometry for the dissolved fraction.

Source regions of zinc in mediterranean
rainwaters

The $\mathrm{pH}$ values for the eleven individual rains collected were found to vary between 4 and 7 (table 1). For each rain sample, three-dimensional backward trajectories of the a1r-masses [Martin et al., 1987] arriving at the $700 \mathrm{hPa}$ barometric level show also a strong relationship between $\mathrm{pH}$ and the geographic origin of the airmasses. Rain assoclated with air masses coming from African regions exhibit higher values of $\mathrm{pH}$ (between 5.8 and 6.9 ) than those resulting from an European or $1 \mathrm{gin}$. These varlations of $p H$ for Mediterranean rainwaters in relation with the origin of the associated air masses are not unexpected. Löye-Pilot et al. [1986] have underlined such a varlability: these high values of $\mathrm{pH}$, which are systematically associated with African dust transport episodes, result from the balancing of the background acidity $\left(\mathrm{H}_{2} \mathrm{SO}_{4}, \mathrm{HNO}_{3}\right)$ by the high contents of calcium carbonate present in the Saharan dust. The acidic spectes are mainiy linked to anthropogenic emissions in the Medi- terranean rainwater. The non marine sulfate represents about $90 \%$ of the total sulfate for the collected "Saharan rains" and nitrate and non marine sulfate exhibit similar concentrations for rains associated to European or Saharan alr masses (table 2).

This can be easily explained by the frontal character of Saharan dust advection over the Western Mediterranean region [Prodi et al., 1979; Bergamett 1 et al., in press, 1988]. The trajectories for the Saharan rains collected confirm these studies. We can observe a strong difference in the origin of the air masses in relation with their final barometric level. The trajectorles ending in the lower layer $(925 \mathrm{hPa})$ show an European origin, while the upper levels (700 or $500 \mathrm{hPa}$ ) Indicate air masses coming from Afican area. A mixing occurs between detritic alkaline air masses from North Africa and polluted alr masses containning sulfuric and nitric acids, zinc and other pollutants. The total zinc concentrations observed in the Mediterranean rainwater confirm this feature; based on the measured aluminium concentrations in ralnwater and the crustal abundances of zinc [Mason, 1966], it can be calculated that less than $10 \%$ of total zinc is of terrigeneous origin in our rain samples,

TABLE 2. Concentrations for soluble and insoluble zinc and an estimate of the contribution in crustal zinc. (Values in $\mu \mathrm{mol.1}-1$, accuracy $6 \%$ for insoluble and $8 \%$ for soluble 2 inc, $10 \%$ for non marine sulfate and $5 \%$ for nitrates.

\begin{tabular}{lcccccc}
\hline Sample & $\begin{array}{c}\text { Soluble } \\
\text { zinc }\end{array}$ & $\begin{array}{c}\text { Insoluble } \\
\text { zinc }\end{array}$ & $\begin{array}{c}\text { Total } \\
\text { zinc }\end{array}$ & $\begin{array}{c}\text { Crustal } \\
\text { zinc }\end{array}$ & $\begin{array}{c}\text { non marine } \\
\text { sulfate }\end{array}$ & nitrate \\
\hline P1 & 2.42 & 0.039 & 2.5 & 0.0014 & 115 & 97 \\
P2 & 0.07 & 0.325 & 0.40 & 0.0228 & 130 & 33 \\
P3 & 0.04 & 0.123 & 0.16 & 0.0126 & 18 & 3.5 \\
P4 & 0.20 & 0.017 & 0.22 & 0.0055 & 21 & 7 \\
P5 & 0.40 & $<0.004$ & 0.40 & 0.0004 & 21 & 9 \\
P6 & 0.24 & 0.051 & 0.29 & 0.0002 & 52 & 13 \\
P7 & 1.22 & 0.377 & 1.6 & 0.0166 & 82 & 55 \\
P8 & 0.11 & 0.256 & 0.37 & 0.0393 & 103 & 63 \\
P9 & 0.29 & 0.069 & 0.37 & 0.0127 & 32 & 23 \\
P10 & 0.11 & 0.012 & 0.11 & 0.0054 & 42 & 24 \\
P11 & 0.13 & 0.008 & 0.14 & 0.0019 & 24 & 15 \\
\hline
\end{tabular}




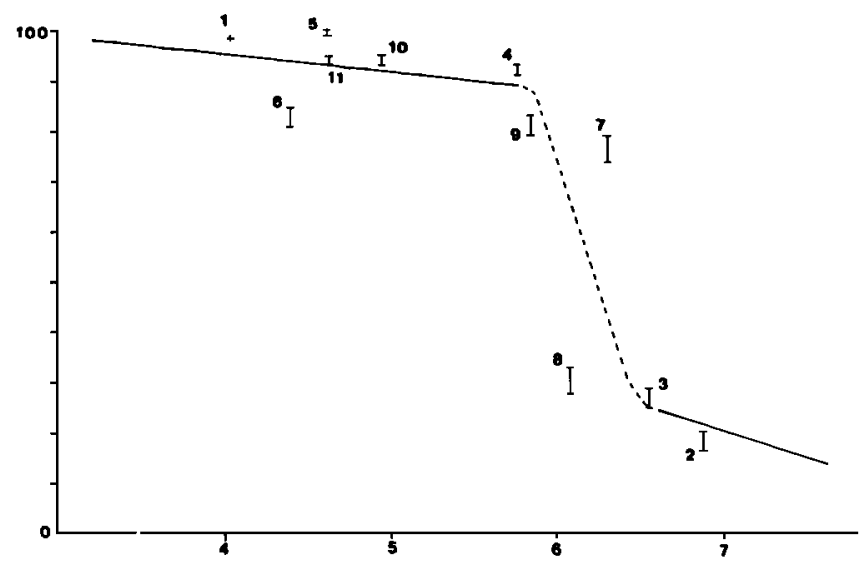

F1g. 1. Percentage of soluble zinc in Mediterranean rainwater as a function of $\mathrm{pH}$.

whatever the origin of the air masses (table 2). Consequently, it $c$ an be concluded in view of the previous discussion, that the zinc present in the Mediterranean rafnwater results strongly from anthropogenic emissions, even in the case of "Saharan raing".

\section{Solubility of zinc}

Figure 1 reports the variations of the percentage of soluble $\mathrm{Zn}$ as a function of rainwater $\mathrm{pH}$. We observe that most of zinc is soluble in the rains which have a $\mathrm{pH}$ lower than 5.5. An abrupt decrease appears in zinc solubility for the higher $\mathrm{pH}$.

One hypothesis to explain our data is a kinetic control of the extraction of zinc from the cristalline lattice. This hypothesis can be ruled out since it cannot explain the abrupt change in the Zn solubility for a narrow pH range and, as mentioned above, the zinc contained in our rain samples was not included in detritic soil minerals.
As previously indicated, a second possibility to explain the zinc behaviour in our rain samples is the formation of insoluble salts. The iontc spectes able to form insoluble salts with zinc are the hydroxides $\left(\mathrm{OH}^{-}\right)$which form $\mathrm{Zn}(\mathrm{OH})_{2}$, the phosphates $\left(\mathrm{PO}_{4}{ }^{3-}\right.$ ) which form $\mathrm{Zn}_{3}\left(\mathrm{PO}_{4}\right)_{2}$ and the carbonates $\left(\mathrm{CO}_{3}{ }^{2-}\right)$ which form $\mathrm{ZnCO}_{3}$ [JoussotDubien, 1962; Seiqueira, 1988]. Taking into account the low ionic strength of our rains, we assume equivalence between concentration and activity. Using the acidity constants for $\mathrm{CO}_{2}$ and $\mathrm{H}_{3} \mathrm{PO}_{4}$, the measured concentrations of $\mathrm{HCO}_{3}{ }^{-}$, phosphorus and pH values, it is possible to calculate the ionic products $\left[\mathrm{Zn}^{2+}\right]\left[\mathrm{CO}_{3}{ }^{2-}\right]$, $\left[\mathrm{Zn}^{2+}\right]\left[\mathrm{OH}^{-}\right]^{2}$ and $\left[\mathrm{Zn}^{2+}\right]^{3}\left[\mathrm{PO}_{4}{ }^{3-}\right]^{2}$. We observe (table 3) that all these 1onic products are significantly lower than the solubility products of these salts. It appears therefore that the changes in zinc solubility do not result from the formation of insoluble salts.

On the other hand, the curve obtained for zinc solubilization (figure 1) is typical of a desorption-adsorption equilibrium. This process has been proposed by White and Driscoll [1987] to explain the partition of zinc in a lacustrine system. The percentage of soluble zinc is about 80-100\% for rainwater with $\mathrm{pH}$ lower than 5.5 and only $20 \%$ for ralnwater with pH greater than 6.5 . This curve of a neutralization type, with a strong decrease of the percentage of dissolved zinc around $\mathrm{pH}=6.2$, is similar to those obtained from a theoretical [Davis and Leckie, 1978] or experimental [Jenne, 1968; Schultz et al., 1987] point of view for zinc adsorption on hydrated oxides. The similitude between the transition $\mathrm{pH}$ of our rains and laboratory experiments [Schultz et al., 1987], suggests that complexing agents, such as organic ligands, have only a little influence on the zinc partitioning in these rainwater samples. The greater mass of insoluble matter in non acidic rains contributes to a greater number of absorption sites, and enhances probably the $\mathrm{pH}$ dependence of the zinc solubility. However, this influence of the number of adsorption sites on zinc solubility can only appear in the range of the $\mathrm{pH}$ transition from 5.5 to 6.5 .

Table 3. Solubility of zinc salts.

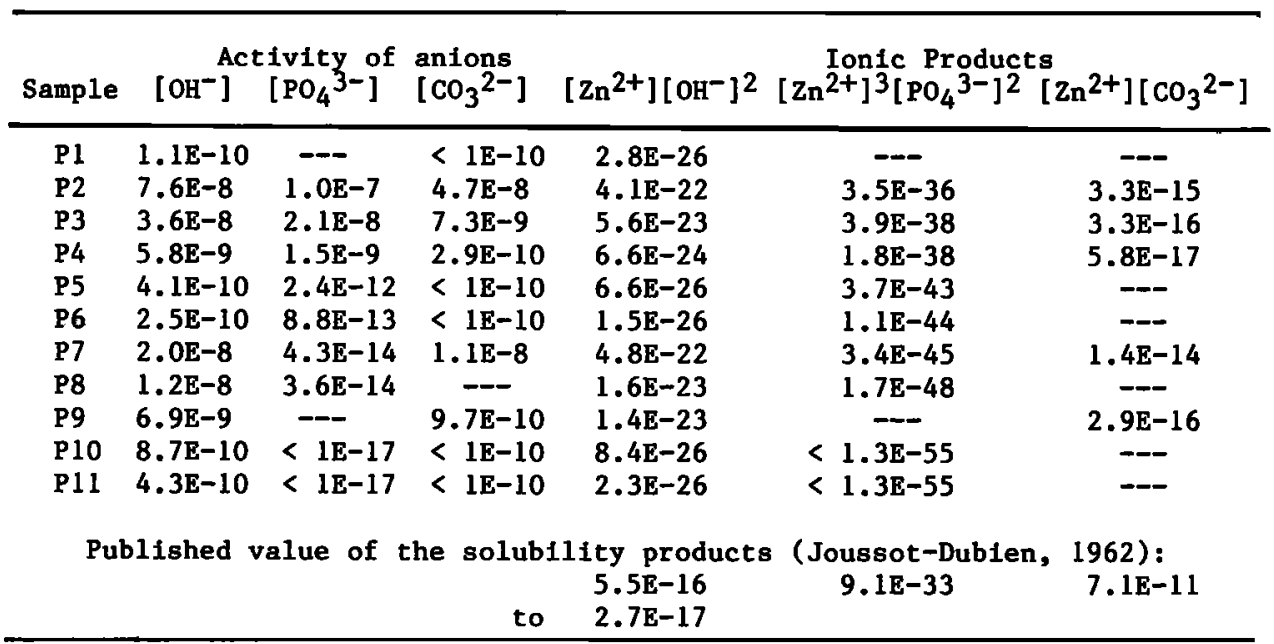


Conclusion

Although the present data set is limited to eleven rainwater samples, our results strongly suggest that the zinc solubility in atmospheric precipitations is controlled by adsorption-desorption processes on existing particles; such processes are largely dependent on the rainwater $\mathrm{pH}$. It should be pointed out that, in our samples, the insoluble zinc is labile, easily mobilized by fast chemical reactions. It can be therefore assumed that the fate of the soluble and insoluble zinc will be largely dependent on the type of natural environment where this element will be deposited. Taking into account the diversity of terrestrial ecosystems, it will be difficult, in this case, to propose a uniform biogeochemical impact for the deposited zinc. On the contrary, in seawater, where the ionic strength is close to 0.3 , pH near to 8 and mineral and organic ligands are abundant, it is probable that most of the wet deposited zinc will be soluble in surface seawater whatever the $\mathrm{pH}$ of precipitations. Consequently, most of the atmospheric flux of zinc to the ocean is likely to be blologically avallable.

\section{Acknowledgements}

We thank the French National Navy which allows the sampling program at Capo Cavallo (Corsica). This research was supported by the CNRS program "Aerosols Désertiques" and the French Ministry of the Environment under grants $84122 \& 87092$.

\section{References}

Benfamin, M.M., and J.O. Leckie, Conceptual model for metal-1igand-surface interactions during absorption. Environ. Sc1. Technol., 15, 10501057, 1981.

Bergametti, G., A.L. Dutot, P. Buat-Ménard, R. Losno, and E. Remoudakf, Seasonal varlability of the elemental composition of atmospheric aerosol particles over the Northwestern Mediterranean. Tellus, in press, 1988.

Cambray, R.S., D.F. Jefferles, and D. Topping, An estimate of the input of atmospheric trace elements into the North Sea and the clyde Sea. Rep. U.R. Atom. Energy Author. AERER7733, 26 pP., HMSO, London, 1975.

Davis, J.A. and J.0. Leckie, Surface ionisation and complexation at the oxide/water interface. II) Surface properties of amorphous iron oxyhydroxide and adsorption of metal 1ons. J. Colloid Interface Sc1., 67, 90-107, 1978.

Eisenrech, S.J. (Ed.), Atmospheric pollutants in natural waters, 512 pp., Ann Arbor Science, Ann Arbor, 1981 .

Galloway, J.N., J.D. Thornton, S.A. Norton, H.L. Volchok, and R.A. Mac Lean, Trace metals in atmospheric deposition: review and assessment. Atmos. Environ., 16, 1677-1700, 1982.

Hardy, J.T. and E.A. Crecelius, Is atmospheric particulate matter inhibiting marine primary productivity ? Environ. Sc1. Technol., 15, 1103-1105, 1981 .

Jenne, E.A., Controls on $\mathrm{Mn}, \mathrm{Fe}, \mathrm{Co}, \mathrm{Ni}, \mathrm{Cu}$ and $\mathrm{Zn}$ concentrations in solls and water: the significant role of hydrous $\mathrm{Mn}$ and Fe oxides. Advances in Chemistry Series, 73, 337-387, 1968.

Joussot-Dubien, J., Zinc, in Nouveau traité de chimie minérale Tome $\mathrm{V}$, edited by Pascal, pp. 31- 330 , Masson, Paris, 1962.

Losno, R., G. Bergametti, and G. Mouvier, Determination of optimal conditions for atmospheric aerosol analysis by $X$-Ray fluorescence. Environ. Tech. Lett., 8, 77-87, 1987.

Löye-Pilot, M.D., J.M. Martin, and J. Morelli, Saharan dust: Influence on the rain acidity and significance for atmospheric input to Mediterranean. Nature, 321, 427-428, 1986.

Maring, H. and R.A. Duce, Impact of atmospheric aerosols on trace metal chemistry in open ocean surface seawater. Earth Planet. Sci. Lett., 894, 381-392, 1987.

Martin, D., C. Mithieux, and B. Strauss, on the use of the vertical wind component in a transport trajectory model. Atmos. Environ., $21,45-52,1987$.

Mason, B. Principles of Geochemistry, 276 pp., J. Wiley and Sons, New-York, 1966.

Moore, R.M., S.E. Milley, and A. Chatt, The potential for biological mobilization of trace elements from aeolian dust in the ocean and its importance in the case of iron. Oceanol. Acta, 7, 221-228, 1984.

Prodf, F., and G. Fea, A case of transport and deposition of Saharan dust over the Italian Peninsula and southern Europe. J. Geophys. Res., 84, 6951-6960, 1979.

Sequeira $\overline{R .,}$, On the solubility of some natural minerals in atmospheric precipitations. Atmos. Environ., 22, 369-374, 1988.

Schultz, M.F., M.M. Benjamin, and J.F. Fergusson, Adsorption and desorption of metal ferrihydrite: reversibility of the reaction and sorption properties of the regenerated solid. Environ. Sc1. Technol., 21, 863-869, 1987.

Stumm, W. and J.J. Morgan, Aquatic Chemistry: an introduction emphasizing chemical equilibria In natural waters, 583 pp., 2nd Ed., J. Wiley and Sons, New-York, 1981.

White, J.R. and T.C. Driscoll, Zinc cycling in an acidic adirondake lake. Environ. Sc1. Technol., 21, 211-216, 1987 .

G. Bergametti and R. Losno, Laboratolre de Physico-Chimie de l'Atmosphère, URA CNRS 676, Université Paris VII, 2 place Jussieu, 75251 Paris Cedex 05, France.

P. Buat-Ménard, Centre des Falbles Radioactivités, Laborato1re mixte CNRS-CEA, 91198 Gif/Yvette Cedex, France.

(Received August 22, 1988; accepted September 30, 1988) 